УДК УДК 811.161.2'373+821.161.2.09

I. О. Іншакова, А. С. Іншаков

\title{
КОЛІРНА ПАЛІТРА В ХУДОЖНІЙ СПАДЩИНІ Т. ШЕВЧЕНКА
}

Т. Шевченка.

Іншакова I. О., Іншаков А. Є. Колірна палітра в художній спадщині

Лексика на позначення кольорів постійно перебуває в колі уваги науковців. У статті розглядається функціонування уживаних у текстах Т. Шевченка кольороназв та ïх похідних. Засвідчено широку сполучуваність кольорономенів, розглядано використання відповідних лексем у прямому та переносному значеннях.

Ключові слова: кольоронайменування, кольорономен, похідні слова, деривати, тематична група, постійний епітет.

Иншакова И. А., Иншаков А. Е. Цветовая палитра в художественном наследии Т. Шевченко.

Лексика для обозначения цветов постоянно пребывает в центре внимания ученых. В статье рассматривается функционирование употребляемых в текстах T. Шевченко цветонаименований и их производных. Зафиксирована широкая сочетаемость соответствующих лексем в прямом и переносном значениях.

Ключевые слова: цветонаименования, цветообозначение, производные слова, дериваты, тематическая группа, постоянный эпитет.

Inshakova I., Inshakov A. The color palette in the artistic heritage of Shevchenko.

Vocabulary to describe colors is always in the center of attention of scientists. The article deals with the functioning of the texts used in the Shevchenko the name of colour and their derivatives. A very broad compatibility appropriate tokens in the literal and figurative meanings.

Key words: the name of colour, color words, derivative words, derivatives, thematic group standing epithet.

Вивчення окремих семантичних груп словникового складу мови $\epsilon$ традиційним в українському мовознавстві. Ідея системності лексики отримала загальне визнання та знайшла своє втілення в дослідженнях українських лексикологів. Серйозні пошуки в галузі історичної лексикології відобразилися в дисертаціях, авторефератах, лексикологічних збірниках, у досягненнях східнослов'янської лексикографії, науковій періодиці, виданнях українських пам'яток. У колі уваги науковців останні 30-50 років перебуває лексика на позначення кольору, зокрема, це й проблема функціонування кольоронайменувань, що досліджується в східнослов'янській мовознавчій літературі (українські лінгвісти М. Чікало, О. Рудь, В. Кушнерик, А. Критенко, Л. Довбня, І. Бабій та ін.; російські мовознавці Н. Бахіліна, В. Москович, Н. Пелевіна, В. Юрик, 
I. Кулікова, М. Суровцева, Н. Степанова, Л. Грановська, А. Панченко та ін.). Кольоративи є розгалуженим, різноманітним із семантичного боку, активним шаром словникового складу української мови. Це одна 3 частотних мікрогруп у лексиці творів Т. Шевченка.

Метою нашої статті є виявлення кольорономенів та їх похідних, аналіз функціонування часто вживаних лексем на позначення кольорів у творчій спадщині письменника.

За словником творів Т. Шевченка номен білий означав «колір крейди, молока, снігу; протилежне чорному» й функціонував зі значеннями: 1) який кольором наближається до білого, світлий, ясний; 2) чистий, випраний; 3) у значенні срібний (про монету); 4) спечений iз борошна найвищого сорту. Лексема вживалася в переносному, образному значеннях: білі палати (СМШ I 29) «про приміщення панів»; білим світом нудити (там само) «томитися, нудьгувати»; білий світ; біла перина (там само II 463) «сніг».

На позначення назви особи жіночої статі трапляється у творах лексема білиця (там само I 29) «невисвячена черниця», ця лексема на сьогодні фіксується у словниках із позначкою заст. (СУМ I 182). Кольорономен білий широко побутує в назвах одягу: біла свитина, білі сорочки (СМШ I 29).

Спорадично трапляються похідні дієслова: обілити (там само II 7) «побілити»; побілений (там само 84) «у спол. костями побілено (про поле) - усіяне кістьми»; побілілий (там само) «вкритий снігом»; nобіліти (там само) «1. стати білим; 2. збліднути; 3. посивіти». Твори автора містять чимало похідних прикметників i значно менше прислівників: біленький (там само I 28) «пестл. від білий, у порівняннях, персоніфікаціях, іронічно (личком біленька, як чумацька сорочка)», білесенький (там само) «пестл. до біленький»; Т. Шевченко часто використовував складні прикметники: білобокий, білокаменна (там само 29) «перен. про Москву», білолиций (там само) «субств. образне про місяць».

Слід наголосити на естетичній функції лексеми, що входить до сполук, уживаних серед фактичного матеріалу, які відображають народне мовлення, фольклорні мотиви. Наприклад, бiлe тіло, бiлe личко, білолищий та ін. Часто вживаними в творчому доробку письменника є типові для фольклору нестягнені форми прикметників: білую, білеє, білії (там само).

У художній спадщині Т. Шевченка лексема чорний позначала «1) колір сажі, вугілля (у порівняльних зворотах: туча... небо 
покрила, як саме чорне сукно; чортенята чорні, мов цицанчата; постійний епітет до слів брови, коси, вуси, очі, галка, ворон); 2) брудний (у тавтологічних сполуках: чорний-пречорний, чорний та nеречорний)»; номен набув i нових значень: «вкритий кіптявою; оповитий темрявою, темний (постійний епітет до земля, поле, нива, крук, галич); перен. злочинний, властивий злочинцеві» (там само II 413).

Власна географічна назва Чорний шлях (там само 414) означала «шлях, який виходив од Дніпра, між устями річок Сокорівки i Носачівки, і біг через степи Запорозькі. Так названий, бо ним татари ходили в Польщу і своїми табунами вибивали траву».

Похідні-назви осіб, успадковані 3 попереднього періоду становлення української мови, що функціонують у контексті поезій автора, сучасні лексикографічні праці часто подають здебільшого 3 позначками церковне, застаріле: чернець, чернечий (там само 405); черниця (там само 406) «жінка - член релігійної громади». Трапляється незначна кількість іменників-назв осіб: чорногори «національність»; чорноморещь (там само 414). Подані в творах зовнішні характеристики збереглися й у сучасній українській мові, наприклад, чорнявий (там само 415) «який має чорне волосся». Постійними епітетами до дівчини, хлопця стали лексеми чорнобривецьь, чорнобривий, чорнобровий (там само 414). Зовнішня характеристика людини часто передається складними дериватами:

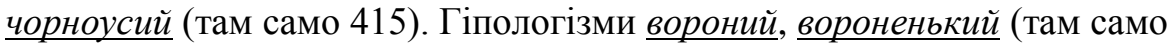
I 114) виступають постійним епітетом до коня, у сполуці ворон-кінь, субстантивоване.

Кольорономен чорний характеризує слова різних тематичних груп - найменування птахів: чорний орел (там само II 413); назви одягу: чорні киреї (там само); інші назви: чорнило «кольорова рідина, що використовується для писання ручкою на папері» (там само 414); чорна печать (там само 413).

Серед похідних фіксуємо різні частини мови, наприклад, дієслова та їхні форми: почорнений, почорнілий, почорніти (там само 141); прислівники: чорніше (там само 414) «у тавтологічній сполуці чорніше чорної землі»; прикметники: у тавтологічній сполуці чорнийпречорний» (там само 659); чорнявенький (там само 415).

Переносні значення кольоратива чорний формують образну семантику фразеологізмів: киснуть (i гнить) в чорнилах (там само 414) «зневажливо про чиновників, канцеляристів».

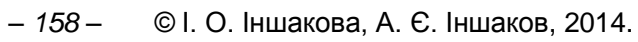


Словник мови творів Т. Шевченка фіксує лексему червоний «1) (жупан, мак, пурпур). Постійний епітет до «калина» // про кров або воду, змішану 3 кров'ю // почервонілий від приливу крові, перен. кривавий. У сполуках а) червоне вино, б) червоний змій - про

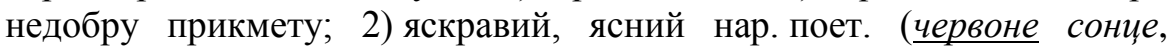
червоний місяць)» (там само 403).

Розглядуваний кольорономен виступає складовою географічної назви Червона Русь (там само 403) «історичне назва місцевості на сході від Карпат»; похідних іменників-грошових одиниць: червонець, червінець, червончик (там само 560).

Виявлені поодинокі приклади номенів червчатий: червчаточка (там само 404) «плахта 3 червоного шовку»; черлений переважно із традиційними значеннями: червлений, червленний (там само 403) «червоний, багряний (червлена риза)»; багряний (там само I 14); чермний (там само II 406).

Серед дібраних прикладів в обстежених текстах функціонують похідні дієслова: зачервоніти, зачервонітися (там само I 268); почервонити, почервоніти (там само 141) «1) стати червоним // вкритися яскравим рум'янцем (про обличчя); 2) перен. зніяковіти, засоромитися (як рак, калина, мак, кармазин) у фразеологічній сполуці ув очах почервоніло (в очах потемніло)»; червонить (там само II 404) «робити червоним», ступеньовані форми прикметників: червоніший (там само 560).

Спорадично трапляються лексеми nypnyp (там само 180) «темно- або яскраво-червоний колір», рудий (там само 217); русий (там само 220).

Дібраний фактичний матеріал презентує новий відтінок червоного кольору - рожевий. Наприклад: рожевий (хмаронька, цзвіт), нестягнені форми рожевая, рожевї (там само 200).

Синій колір та його відтінки в текстах передавалися різними лексемами: синій, синенький (там само 249); синіти (там само 250); засиніти (там само I 261); блакитний (там само 33).

Матеріали словника свідчать про розширення тематичної сполучуваності лексеми голубий: голубий (небо, жупан), наявність нестягненої форми прикметника голубеє (там само 143).

Лексема жовтий уживалася на позначення кольору шкіри, шкіряних виробів (конкуруючи з лексемою червоний): жовті черевики (там само 230); навколишнього природного середовища: жовте листя, жовте поле (там само); була твірною для похідних дієслів 
жовтіти (там само 231); пожовклий (там само II 100). У джерелах зафіксовано демінутив жовтенький: жовтенький пісок; жовтесенький пісок (там само I 230).

Номен золотий виступав не лише як відносний прикметник, а й у ролі якісного, передаючи кольоронайменування: золотий (там само 292) «1) зроблений із золота, оздоблений золотом, позолочений // тканий золотом; 2) субств. золота монета; 3) жовтогарячого, як золото, кольору; 4) перен. надзвичайно багатий // розкішний; 5) перен. квітучий, щасливий».

Особливістю похідних від кольорономена золотий є значна кількість прикметникових складних дериватів, що часто передають образність, емоційність. Наприклад: золотокрилий (херувим, пташечка), золотополий (лан), золотофилий (лан) (там само 293). Індивідуально-авторські новотвори письменника є свідченням дериваційного потенціалу аналізованої кольоролексеми. Наприклад: золотокрилий, златозмальваний.

Розширюється коло значень кольорономена сірий, пор.: сірий (Кв.-Осн. III 223) «колір, середній між білим і чорним, у сполуці сіре сукно «грубе, небілене сукно»; сірий (СМШ II 252) «1) похмурий (про небо); 2) постійний епітет до назв деяких представників тваринного світу (гуси, птах); 3) перен. нещасний, убогий». Традиційно, як і раніше, побутує група назв одягу, тканин: сіряк (там само 253) «1) верхній одяг бідняків; 2) перен. про бідну людину».

У текстах виявлена незначна кількість похідних назв осіб: cipoмa (у прикладці сірома-сирота), сіромаха (там само 252) «нещасна людина». П. Куліш зауважував, що коли мовиться сіромаха, сіроманець про вовка, то це сірий колір шерсті, про людину свідчить непрямо про убозтво, злиденність не дозволяє носити кольорового одягу, а водночас приписує людині щось вовкообразне, бродяче, бездомне. Групу назв тварин представляє лексема сіроманець (там само 253) «вовк».

Серед похідних прикметників часто подибуємо деривати: сірісінький (образне тавтологічне сірісінький сіряк) (там само 252); нестягнені форми прикметників cipiï, cipaя (там само); тавтологічна сполука сірі сіромахи (там само); складні слова сіроокий (там само); темно-сірий (про масть коней).

Словник фіксує значну кількість похідних від прикметника сивий, серед них чимало складних дериватів: сивенький, сивесенький (дідусь) (там само 245); сивий (там само) «1) ус, коси, брат, голова // субств. образна; 2) сизий, сірий (туман, пугач) // про коня - сіро- 
чалий»; сивобородий, сивоволосий, сивоусий (там само). Джерельна база засвідчує незначну кількість похідних дієслів: сивіть (там само); посивіти (там само 129).

Із давнини мав обмежену сполучуваність прикметник сизий (там само 246) перен., фольклорне «у сполученні 3 іменниками голуб, голубка, голубонько при ласкавому звертанні до кого-небудь». Номену сизий була властива вузька кольорова семантика, позначав виключно колір птаха. Уживається слово для назви оперення птахів у пам'ятках із фольклорними мотивами в давніх звичних сполученнях. Наприклад, сизокрилий (там само).

Прикметник сідий традиційно позначав колір волосся (символ мудрості, старовини): ciduй (там само 252); складний дериват сідоусий (там само).

Словник мови творів Т. Шевченка репрезентує гіпологізми гнідий (там само 477); буланий (там само I 49); половий (там само II 113); карий (там само I 316).

Лексема карий виступала постійним епітетом до іменника очі: зафіксовані нестягнена форма прикметника оченята карії (там само 316); складний дериват кароокий (там само 317).

Кольорономен зелений міг позначати природний ландшафт: зелений степ (там само 278); назви одягу зелений жупан, зелені шаровари (там само); бути твірним для похідних дієслів зеленіти (там само); зазеленіти (там само 246); позеленіти (там само II 101). Тексти засвідчують різноманітні форми прикметників: зелененький (там само I 277); зафіксовані стійкі сполуки термінологічного характеру: зелена неділя (зелені святки) (там само 278).

Отже, кольори в творчості Т. Шевченка, як і в житті українців, відігравали неабияку роль, символізуючи певні грані людського буття. Назви кольорів автор уживає як у прямому, так і в переносному, образному значеннях. Для створення художніх образів письменник використовує широкий спектр відтінків кольорів для відтворення власного світосприйняття та естетично-художньої позиції. Кольорова гама контексту поглиблює ідейно-тематичний задум творів. Часто семантика кольороназв спирається на народно-поетичну основу.

\section{Література}

1. Критенко А. П. Колір i барва в поезії Тараса Шевченка / Афанасій Петрович Критенко // Мовознавство. - К., 1967. - № 4. - С. 63-74.

2. Мойсієнко А. К. Епітет у поезіях Т. Шевченка / Анатолій Кирилович Мойсієнко // Українська мова в процесі національно-культурного відродження України : зб. наук. праць / відп. ред. Л. І. Мацько. - К. : КДПІ, 1993. - С. 145-150.

ㅇ. І. О. Іншакова, А. Є. Іншаков, $2014 . \quad$ - $161-$ 


\section{Список скорочень джерел}

Кв.-Осн. Словник мови творів Г. Квітки-Основ'яненка : у 3-х т. - К. : ХДУ, 19781979. - T. 1-3.

СМШ Словник мови Шевченка : у 2 т. - К. : Наукова думка, 1964. - Т. 1-2.

СУМ Словник української мови : в 11 т. - К. : Наукова думка, 1970-1980. - Т. 1-11. 